\title{
Internalization of Character Education in Era 4.0 as A Moral Conservation Solution for Students in Kupang City
}

\author{
Amirulah Datuk ${ }^{1, *}$ Arifin $^{2}$ \\ ${ }^{1,2}$ Sociology Education,Universitas Muhammadiyah Kupang, Kupang, Indonesia \\ *Corresponding author. Email: amirulahdatodawa@gmail.com
}

\begin{abstract}
The social and cultural conditions of students, from cities to remote villages, have been worrying lately.Education faces a social pathology that is almost at a chronic level where kindness, polite, courtesy, honest and responsibility as self-identity are lost with the times, replaced by the production of negative behaviors that tend to be destructive, such as promiscuity, drugs, pornography, porno-action, mass cheating behavior, to the educated elite level, namely the practice of corruption, collusion and nepotism. This moment is where education must be present as a collective responsibility to provide answers to the excitement in improving the character of the nation in the era of the industrial revolution 4.0.The commitment of all education stakeholders in the era of the industrial revolution 4.0 is to strengthen character education with the principle that character education can change according to the demands of the times when all elements of education carry out character values development activities consistently and together. For this reason, the role of family, school and society is very important in order to create a generation that is moral, has noble character and character to be ready to face globalization competition.
\end{abstract}

Keywords: Education, Social Conditions, Character

\section{INTRODUCTION}

The reality of our national life today there is a shift in an order of character values which is getting more and more concerning. Pessimism suddenly appeared when he saw the crisis in character values as if it indicated that all the knowledge he had obtained in school had not yet had an impact on changing Indonesian human behavior. Demoralization occurs because the learning process tends to be "dry", even if it teaches character education and it is limited to text, and does not prepare students to respond and face contradictory lives. Cultivating character is an urgent matter that should be given to students in any emergency situation, including the Covid-19 era, so that the nation continues to give birth to a generation that has a good self-concept as an individual, a group and as a nation and state. This is marked by efforts to fulfill the demands of the times with 4 (four) aspects, namely (1) education upgrading the quality of the curriculum, (2) providing internalization of values, (3) raising awareness of changing times, and (4) bringing students to discover concepts. self, [1].
The phenomena that appear at this time are quite surprising, especially for the world of education, ranging from student brawls, promiscuity, drugs, pornography, porno-action, mass cheating behavior, student pimps peddling their friends, to making nasty videos in classroom. This phenomenon jolts our collective awareness, whether education has failed to achieve its goals, namely shaping a noble personality and character, not to mention the problems related to corruption, collusion, nepotism and the low spirit of nationalism. The reality of the nation today is experiencing a form of moral degradation or character crisis. Many cases that smell negative have appeared on the public surface. This problem is actually carried out by educated people. It is an indication that the practice of corruption, collusion and nepotism is actually dominated by educated people. As if the reality has tarnished a concept regarding the purpose of education as stated in Law number 20 of 2003 concerning the National Education System article 3, namely "national education functions to develop capabilities and shape the character and dignity of the nation in order to educate the nation's life, aimed at developing it. students to become human beings who believe in and fear God Almighty, have 
noble character, are healthy, knowledgeable, competent, creative, independent and become democratic and responsible citizens. [2].

According to Muchtar Buchori, 1994, in Dian Arif N. Pratama [3]. states that Indonesian people still regard education as a means, not as a goal. Moreover, the society also views the education as a "stepping stone" to improve social status.

In this concept, if education is only a means, it will certainly be trapped in formality. Whatever is done with the concept of getting a reward without having the knowledge and life skills (live skills). Education is initiated as a goal that appears in the educated self, so that is the end of the educational process. These two concepts suggest that education is an integrated process with supporting means by involving students, educators, learning mediums, learning objects, learning processes, and the ultimate goal of learning. Education is initiated as a goal that appears in the educated self, so that is the end of the educational process. These two concepts suggest that education is an integrated process with supporting means by involving students, educators, learning mediums, learning objects, learning processes, and the ultimate goal of learning. Students are those who are ready to do learning, the learning medium is the reality of life, the object of learning is the life problems faced, and the process is the flow that students pass in the learning space (Mu'arif, 2008). The final point of education is the ability in the form of insight and life skills along with affective change. This is where education is getting closer to the meaning of the process of changing the behavior of students' lives. It is true what Propert Lodge said "Live is education and education is live"[4].

He admitted, the issue of character or morals was not completely ignored by educational institutions. However, the facts surrounding the deterioration of character around us show that there has been a failure in educational institutions to develop Indonesian people with noble character and morals. This is because what is taught in schools about religious knowledge, Civics, aqidah, and moral education has not succeeded in shaping human character. In fact, if you look at the contents of all the subjects, everything is good, and we can even memorize and understand them, [5].In this case, educational institutions, both primary, secondary and tertiary education, are expected to make a big contribution in preparing students to become leaders in the future.
In this context, character of education ia an educational movement that supports students'social, emotional, and ethical development.Ths is a proactive effort by schools, regions, and the state, in terms of instilling in students the values of ethics and performance, such as : caring, honesty, perseverance, fairness, fortitude, responsibility, and respect for self and others. Character education provides long-term solutions to moral, ethical problems, and academic issues that are getting more attention in society and school. Character education teaches students to be their best selves and how to do their best work. Because of character education must be an identity that reflects the real identity of students. If they are smart, but they do not have a character value as described above, then all is in vain.

Character education that is implemented at schools are not taught in special subjects, but it is carried out through daily learning that has taken place at school.Deputy Minister of National Education, Fasli Jalal in Sri Judiani, [6]. said that character education that the government encourages schools to implement will not be a burden to teachers and students. Because of the value of character education in character education is actually already in the curriculum, but so far it has not been taught explicitly. We ask the teacher that the values contained in subjects and extra curricular activities are clearly conveyed to students. Character education can be integrated into school culture. So, character education that is going to be implemented nationally does not burden the existing curriculum. Character education that can be build national insight, and encourage students'inovation and creation.Besides that, the values that need to be built in the nation's future generation such as : honesty, hard work, cooperation, tolerance, respect for differences, and discipline. Each school is free to chose and to apply the values to be built in stusents, even the government encourages the emergence of diversity for the implementation of character education. School programs such as: scouts, honesty canteen, and green school.

Globalization gives birth to socio-cultural issues which cause problems to become increasingly complex. Globalization has a positive impact as well as a negative impact on humans. A nation that has a tough character usually grows and develops more and more prosperously. So it is important that humans with character values in themselves make assets for themselves in the future and assets to advance the nation. That way, the strategy in shaping the character of every human being is very vital in implementing it. That way 
education in shaping the character of every human being is the initial foundation to become an individual with good personality, quality, so as to make a civilized and advanced nation. [7].In this context, character education are: (1) development; (2) improvement; (3) filter. Development is the potential of students to become individuals who behave to reflect the character of the nation. Improvement namely strengthening the progress of national education to be responsible for developing the potential of more dignified students. Filter, namely to select the culture of own nation and culture that are not in accordance with the values of a dignified character.

The industrial revolution is currently entering its fourth phase. The very rapid development of science and technology has a great impact for human life. Many conveniences and innovations are obtained with the support of digital technology. The service becomes faster and more efficient, and it has a wider range of connections with the range of connections with the online system. Life becomes easier dan cheaper. However, thr digitalization program alsa had a negative impact. The role of humans are graduallty taken by automatic machines.As a result, the number of unemployed is increasing. Therefore, to take advantage of opportunities and answer the challange of the 4.0 industrial revolution, office holders must have the data, technology, and human literacy skills [8].

Currently, the world has entered the era of the 4.0 generation industrial revolution marked by increased connectivity, interaction and development of digital, artificial intelligence and virtual systems. With the increasingly convergent boundaries between humans, machines and other resources, information and communication technology will certainly have an impact on various sectors of life. One of them is having an impact on the education system in Indonesia. The change in this era cannot be avoided by anyone, so that adequate preparation of human resources (HR) is needed to be ready to adjust and be able to compete on a global scale. Improving the quality of human resources through education from primary and secondary education to tertiary institutions is the key to being able to keep up with the development of the Industrial Revolution 4.0 [9].

Now, the whole world of education in Indonesia, especially in Kupang city has undergone enormous changes. With the digital transformation, cost efficiency and productivity as well as improving the quality of education will lead to be a good system. [10]. The world of education in Kupang City is working hard to prepare its students to live in the Industrial Revolution Era 4.0 (four point zero), namely the fourth world industrial revolution where information technology has become the basis of human life. This era also disrupts various human activities, including in the fields of science and technology. The changes that occur due to digital technology have resulted in disruption which will change many aspects of human life in the future, including the learning patterns and attitudes of students. Therefore, the educational builder that must be prepared is the mental construction that must be formed through the world of education. Because education is an investment, and the benefits are not material, but rather a wealth of knowledge, increased skills and changes in attitudes, mental and character to become fully human beings who are ready to survive in the era of the Industrial Revolution 4.0 (four point zero).

\section{METHOD}

This type of research is library research (library research) with a descriptive qualitative approach. Sources of research data are descriptions, descriptions and writings that are referred to from sources related to research problems, both in the form of books, journals and articles (Cheswell, 2010). The data collection technique used as a tool for collecting data in this study is the documentary technique: that is, the data is extracted through documents from various library materials, then analyzed using content analysis. With this technique, qualitative data is sorted, categorized (grouped) with similar data, then the content is analyzed critically so that a concrete formulation is formulated which is then explained in depth, [11]. Further arguments related to the method used in literature research are research that is identical to the activity of analyzing text or discourse that investigates an event, whether in the form of an act or writing that is researched to obtain accurate conceptual and theoretical facts. The concept of the author using in this method are; first, discovery, second, proving, and third, development.

The discovery, if the data obtained from the research is new data and has never been known. Proving, if the data obtained from research are used to prove the existence of doubts about certain knowledge. And development, if the data obtained is used to deep and expand the knowledge.

\section{RESULT AND DISCUSSION}

\subsection{The Role of Education in Kupang City to instill the Character Values of Students in the Industrial Revolution Era 4.0.}

The role of education in preparing generations in the current era of the industrial revolution 4.0 is to prepare graduates who are able to interact with humans from 
various parts of the world and of course be equipped with strong social and emotional interpersonal and interpersonal skills. The criteria for graduates declared by the Indonesian government are currently in accordance with the 2013 curriculum where graduates are required to have the ability to:

1) Troubleshoot problems. This ability is very useful for graduates so that they can be used in dealing with various situations and the risks that accompany them, which of course will have more and more varying levels of complexity in the fast-paced and uncertain situations of the 21 st century.

2) Think critically. This ability is also very much needed when graduates are faced with problems that involve many things and their decision making will certainly have an impact on themselves and others.

3) Innovative. Problem solving and critical thinking skills that are expected to be possessed by graduates must contain novelty, because everything in this era also has novelty from various sides. When graduates are not trained to find novelty in the problem-solving process and in the process of thinking, of course the decisions taken will lead to solutions that may lead to other problems.

4) Enterpreuner. In this 21 st era, it is very possible for a number of professions to decline or even disappear that existed in the previous era and be replaced by new professions. For example, currently there is a profession that is referred to by YouTubers. A profession which in its business uses one of the YouTube virtual world applications to market products. The content displayed can vary widely. Anyone can watch the results of these YouTubers in just seconds and with ease. The ability needed is an entrepreneurial spirit. A skilled soul thinks about how a product can be attracted by the market so that it can make money, [12].

Since ancient times until the current era of the industrial revolution 4.0, all aspects of human life are not free from values. Therefore, in education it is also appropriate to teach values like Lickona's expression, as quoted by Zidniyati that:

"Schools must make a clear and whole-hearted commitment to teach moral values and develop good character is that the role of schools as moral educators becomes more important at a time when millions of children receive little moral learning from their parents or less access from religious education centers. in middle childhood. A time when, supposedly, children get moral examples or character building values from their immediate environment. Lickona continued to formulate a character development process that can be done by instilling commendable character-building values through three stages, namely moral knowing, moral feeling, and moral action. This character development process begins with giving students an understanding of a moral value, followed by involving students emotionally in the values taught so that students believe that these moral values need to be used as a guide in their lives, and interpreted by habituation to behave according to these values. Indeed, the time needed to develop positive character in students is not short. But along with the development task, the character of each student can be developed continuously"[13].

In this context, the educational process in Kupang City in the context of internalizing character education in the era of industrial revolution 4.0, the design of the learning process is expressed as its true meaning, namely:

"In accordance with the needs of students who live in the 21 st century, it is not just a process of transfer of knowledge, but also what needs to be done is the transformation of values and personality formation with all the aspects it covers. So that teaching is oriented towards the formation of scientific specialists or certain fields, by strengthening the values of character, norms of courtesy, cultural content typical of the people of Kupang city, and religious values. Because education is a process that is needed to get balance and perfection in individual and community development. The emphasis of education compared to teaching lies in the formation of awareness and personality of the individual or society as well as the transfer of knowledge and expertise. With this kind of process a nation or state can pass on religious values, culture, thoughts and expertise to the next generation, so that they are truly ready to face a brighter future of the nation and state, [14].

This character education means making serious, systematic and sustainable efforts to raise and strengthen the awareness and belief of all Indonesians that there will be no better future without building and strengthening the character of the Indonesian people. In other words, 
there is no better future that can be realized without honesty, without increasing...self-discipline, without persistence, without a high spirit of learning, without developing a sense of responsibility, without cultivating unity in the midst of diversity, without the spirit of contributing to mutual progress, and without selfconfidence and optimism. School is one of the right places to develop character education for children. Quoting from Roosevelt in the book Putu Yoga Purandina: "To educate a person in mind and not in morals is to educate a menace to society" (Educating someone in the intelligence aspect of the brain and not the moral aspect is a threat of harm to society)[15].Character development in a school functions and involves a learning environment to spark, pioneer, perfect and preserve the continuity of character education in educational units or schools. Therefore, it is necessary to prepare a special method in an effort to prepare and integrate all educational values and character so that there is a balance between mastery of the field of science and non-academic abilities is a mandate to improve the quality of life of the nation.Moral degradation and cultural crisis have become a routine phenomenon that has drowned the nation's honour and dignity.

\subsection{The challenges that will be faced by education in Kupang City are related to the character of students in the Industrial Revolution Era 4.0.}

As time goes by, currently human civilization has entered there of the industrial revolution 4.0. An era where information and communication between people living in the northern hemisphere to the south becomes very fast and feels close. Through internet-based network access, all information that humans need can be obtained only by utilizing a device equipped with highlevel Android facilities by browsing the virtual world using search engine. It doesn't take long, just seconds various information and transactions until decisions can be made.

"The fourth industrial revolution or often referred to as Industry 4.0, said that the industrial revolution occurred four times. In 1784 the industrial revolution occurred in England, namely the invention of the steam engine and began to replace human jobs. At the end of the 19th century the second industrial revolution occurred, how machines that are produced using electricity are used for universal production activities. in 1970 became the answer to the third industrial revolution, the use of computer technology. The next industry is 4.0, how the term was born in Germany to be precise when the Hannaver Fair was held in 2011. The German state has a great interest in part of its development policy called the HighTech Strategy 2010. The policy aims to keep Germany always being at the forefront of manufacturing "[16].

Through a form of communication that is so fast, which requires readiness that needs to be done by students in the city of Kupang to prepare themselves to face the changes in the era of the Industrial Revolution 4.0. Because the era of the Industrial Revolution 4.0 all business transactions can be carried out quickly and much more efficiently than conventional methods, all forum discussions can be carried out remotely, all decisions can be made even if the discussion members are in different places. Adults, teenagers, and children today can connect and access various information from all over the world. Then the forms of education can take their role appropriately in this industrial revolution era. Education in Kupang city must take an important role in making a real contribution to preparing students to be ready to survive in the era of the Industrial Revolution 4.0 by having three skills, namely cognitive, affective and psychomotor.

Lickona formulated the process of developing character education in the era of the Industrial Revolution 4.0 by instilling commendable character building values through three stages, namely:

moral knowing (knowledge of moral), moral feeling (feeling about moral), and moral action (moral action). This character development process begins with giving students an understanding of a moral value, followed by involving students emotionally in the values taught so that students believe that these moral values need to be used as a guide in their lives, and interpreted by habituation to behave according to these values. Indeed, the time needed to develop positive character in students is not short. However, along with the development task, the character of each student can be developed continuously, [17].

The challenge of character education for students in Kupang City in the era of the industrial revolution 4.0 
that is being experienced today is where students interact more by using a sophisticated device, namely mobile. Character is essential for everyone.

Character also characterizes each individual with one another. Even character distinguishes humans from other living things, [18]. In simple terms, character education for students in Kupang city can be internalized as early as possible as an effort that can be made to influence changes in student character as well as preparation for them to live in the era of the industrial revolution 4.0 where they are not they are only smart in mastering science, but they are also in attitude and character which must characterize as educated people who respect each other, respect others as one unity in Indonesian society. Thomas Lickona stated that character education is a deliberate effort to help someone so that he can understand, pay attention to, and practice core ethical values. Starting from this definition, when we think about the type of character we want to build in students, it is clear that at that time we want them to be able to understand these values, pay more attention to the true value of these values, and then do what he believed, even though he had to face challenges and pressures both from outside and from within himself. In other words, they have an "awareness of compelling themselves" to do these values both for themselves and for others.

In order to prepare the golden generation who will live in 2045, the students must be prepared from an early age about the value of character education for students in Kupang city as a reference for living the future life.

According to Lickona in Amirullah Datuk, the reasons for the need for character education must be formed from an early, for several reasons as follows : (1) Many students at school injuring each other are due to a weak awareness of moral values, (2) Giving the value of moral education to the younger generation is one of the most important function of civilization, (3) The role of teachers in school as character educator becomes increasingly important when many children receive less moral instruction from parents, society, and religious institution, (4) There are still moral values that are universally accepted, such as; attention, beliefs, respect, and responsibility, (5) Democracy has a special need for moral education because it is the rule of, for, and by society, and (6) effective character education makes schools more civilized and cares for the society [16].

Industry 4.0 has great potential benefits but also has big challenges if you are not wise in dealing with it, it will be a big threat to human life.

With this versatile and sophisticated era, humans are increasingly spoiled by technology, humans are increasingly thinking in an instant, so that human character is increasingly eroded by the times. So that the industrial era 4.0 becomes a disruption / problem for humans who are not wise in facing this era. With easy internet access, there are many shows that are not suitable to be a guide for the community, especially students who are still looking for identity, almost all of them are busy with their cellphones because they want to express themselves in social media. That way mobile phones with internet access are more deified than god, teachers who should be humanized in education become friends without limits, in the end there is no manners embedded in students, because of the loss of noble character / morals in humans. [19]

In the context of facing the challenges of character erosion in the era of the industrial revolution, it is necessary to pay attention to the following points in accordance with what was proposed by Thomas Lickona, 1) The best way to ensure that children (students) have good personalities in their lives. 2) Ways to improve academic achievement. 3) Some students cannot form strong characters for themselves in other places. 4) Preparation of students to respect other parties or people and to live in a diverse society. 5) Departing from the root of the problem related to moral-social problems, such as immodesty, dishonesty, violence, sexual activity violations, and a low work ethic (learning). 6) The best 
preparation for welcoming behavior in the workplace. 7) Learning cultural values which are part of the work of civilization.

\subsection{The Strategy for the Implementation of Character Education that must be implemented to prepare Kupang City Students in the era of the industrial revolution 4.0}

The strategy for implementing character education in schools can be carried out in four ways, namely: (1) reinforcing, (2) modeling, (3)teaching, and (4) habituating. The effectiveness of character education is very much determined by the existence of teaching, modeling, reinforcing, and habituating which are carried out simultaneously and continuously. This strategic approach to implementation involves three interrelated components, namely: (1) school, (2) family, and (3) community.

In order to internalize the values of Character Education to prepare students in the city of Kupang in the era of the industrial revolution 4.0, the following things must be done: 1) The school component must fully implement and implement the values (priority characters), then each value will be implanted. teachers must always convey or practice it through direct learning (as a subject) or integrate it into each subject, 2) These priority values must then be modeled (exemplified) regularly and continuously by all school members, since parking attendants, cleaners, security guards, administrative staff, teachers, and school leaders, 3) Furthermore, these values must be strengthened by environmental arrangements and activities in the school environment. The environmental arrangement here includes placing banners that lead to and provide support for the formation of an atmosphere of school life with a commendable character, and 4) Habituation can be done at school in various ways and involves many things such as time discipline, dress ethics, social ethics, student treatment of employees, teachers, and leaders, and vice versa. The habituation carried out by leaders, teachers, students, and employees in the discipline of an educational institution is a very strategic step in shaping the character together, [19]

In this context, the inculcation of national character values must be instilled through a small scope in educational institutions, namely the class environment. Cultural values in accordance with our country must be embedded in the soul of every student so that there is no lost generation in terms of culture and national character.

The purpose of the educational process should be oriented towards a balance of three elements of education, namely character, knowledge and soft skills. So, education is not only realizing students who are intelligent in the brain, but also have intelligence in heart and body. The development of education always changes along with the times, the wider of access to the interaction, the wider of the challanges. Education in the past was enough to make chilfren obedient, and easy to manage, even though the function of education was unbalanced and played a greater role in education based on the school environment. However, the results are satisfactory in shaping the character and personality of the child. To realize the dream of character education, it is necessary to have an awareness of learning and teaching. The educators must change the mindset in teaching, habits, family and society, so that they can be actively involved. The involvement of educators in those three environments above are believed to be able to neutralize the negative aspects caused by the sophistication of globalization [20].

The character values of students are very important points of educational assignments. Education continues to provide goodness which is marked how to apply the value of goodness in the form of actions or behavior, so that if a person is greedy, a liar, corruption, grumpy, arbitrary and other bad behavior, then that person is said to have a bad character. Vice versa, if the person behaves in accordance with moral norms and rules, he is called a person with noble character. That is the hope of products from education in the era of the industrial revolution 4.0, namely how to be smart, have character and have skills.

The Ministry of National Education as a locomotive in character implementation has formulated the basis as a reference in instilling the character values of students, the Ministry of National Education determines 18 character values as quoted by Sari and Widiyanto in Arifin (2019) as follows: (1) religious, (2) discipline, (3) tolerance, (4)honest, (5) hard work, (6) democratic, (7) independent, (8)creative, (9) curiosity, (10) love of the country, (11)spirit of nationality, 12) respect for achievement, (13) likes to read, (14) love peace, (15)friendly/communicative, (16) cares about the 
environment, (17)responsibility, and (18) cares about social.

The character values above are described as follows:

1. Religious: obedient attitudes and behaviors in implementing the teachings of the religion they adhere to, tolerant towards the practice of other religions, and live in harmony with adherents of other religions.

2. Honest: behavior based on efforts to make himself a person who can always be trusted in words, actions, and work.

3. Tolerance: attitudes and actions that respect differences in religion, ethnicity, ethnicity, opinions, attitudes and actions of others who are different from oneself.

4. Discipline: actions that show orderly behavior and comply with various rules and regulations.

5. Hard work: behavior that shows serious efforts in overcoming various obstacles to learning and assignments, and completing tasks as well as possible.

6. Creative: thinking and doing something to produce new ways or results from something that is already owned.

7. Independent: attitudes and behaviors that are not easily dependent on others in completing tasks.

8. Democratic: a way of thinking, behaving and acting that values the rights and obligations of oneself and others.

9. Curiosity: attitudes and actions that always seek to know more deeply and broadly from what they have learned, seen, and heard.

10. National Spirit: a way of thinking, acting, and with an insight that places the interests of the nation and the state above the interests of themselves and their groups.

11. Love the Motherland: a way of thinking, behaving, and acting that shows loyalty, concern and high respect for the nation's language, physical, social, cultural, economic and political environment.

12. Respect Achievement: attitudes and actions that encourage him to produce something useful for society, and recognize and respect the success of others.

13. Friendly / Communicative: actions that show a sense of pleasure to talk, socialize, and cooperate with other people.
14. Love Peace: the attitude of words and actions that cause other people to feel happy and secure in his presence.

15. Loving to Read: the habit of taking time to read various readings that benefit him.

16. Environmental Care: attitudes and actions that always seek to prevent damage to the surrounding natural environment, and develop efforts to repair natural damage that has occurred.

17. Social Care: attitudes and actions that always want to provide assistance to other people and communities in need.

18. Responsibility: a person's attitude and behavior to carry out his duties and obligations, which he should do, to himself, society, the environment (natural, social and cultural), the country and God Almighty, [21]

The eighteen character values mentioned above are a massive internalization strategy implemented by the school as the spearhead for implementing the internalization of the character values of students in Kupang City. Strategies that must be carried out in the era of the industrial revolution 4.0 in the context of internalization, according to Helmawati, which Dian A. Pratama recommended, recommends that there are five strategies that can form children with character in their personalities, including: 1) a little teaching or theory, 2) lots of examples, 3) a lot of habituation or practice, 4) a lot of motivation, and 5) consistent supervision and enforcement of rules as follows:

1. A little theory teaching: if character education is to be successful, of course education must have a little teaching (a little theory) and increase practice.

2. Many role models: modeling in education is the most influential method for children. Children see, listen to and socialize with their parents for the first time; This means that the words and actions of the parents will be imitated by their children. In this case, parents as first and foremost educators are the best examples in the eyes of children.

3. A lot of habituation or practice: habituation is a condition in which a person applies behaviors that have never or rarely been carried out to be carried out frequently until they eventually become habits.

4. Lots of motivation: humans have a spirit that sometimes fluctuates, so when humans are in a state of spirit they need to be motivated. Humans 
have the potential that when motivated they will show better performance. Motivation has a very good and positive impact on human psychological development, especially the development of children's education.

5. Consistent supervision and enforcement of rules: in order for someone to remain an upright and true person or individual there needs to be supervision and enforcement of rules. Because someone who feels watched will always try to be a good and right person.

Those five points are important recommendations as an agenda that must be prepared and carried out by education stakeholders in Kupang City in order to prepare students as early as possible to compete in the era of industrial revolution 4.0 which has good character values. In fact, character education has long been an important part of the ups and downs in our national education curriculum, both explicitly and implicitly. It is a fact in the history of our curriculum, whether we realize it or not, that national education programs always include the importance of character education in every policy. Hope in the future with the challenges that come and go, this form of policy regarding character education is always applied and implemented in activities developed by schools in each subject.

\section{CONCLUSION}

Internalization of character education in the era of the industrial revolution 4.0 is very important with the aim that the nation's future generations have good moral and moral behavior. Education in the era of the industrial revolution 4.0 is to strengthen character education with the principle that character can change according to the opportunities and learning environment that is created. Character education can be successful when all elements of educators carry out activities to develop character building values consistently and together. For this reason, the role of family, school and society is very important in order to create a generation that is moral and has noble character. The process of character development begins with giving students an understanding of a moral value (moral knowing), followed by emotional involvement of students with the values taught so that students believe that moral values need to be used as a guide in their lives (moral feeling), and interpreted as habituation. behave according to the believed value (moral action).
As the last past of the writing in this paper, the author recommends the important things to consider in shaping the character of Indonesian students, especially, for the students in Kupang city, regarding the importance of developing character education from an early age as follows: (1) Focus on developing the affective potential of students, so that they understand theirselves as humans and citizens who have national character values; (2) Inculcate the habits and behavior of students that are commendable and in line with universal values and religious traditions or national culture; (3) Give the motivation to the students related to the spirit of leadership and responsibility of students as the next generation of the nation; (4) Develop the ability of students to become independent, creative, nationalistic, and (5) Develop the school environment as a learning environment that are save, honest, full of creativity, friendship and has a strong, and a strong sense of nationality.

\section{REFERENCES}

[1] M. S. Assingkily dan M. Miswar, "Urgensitas Pendidikan Akhlak Bagi Anak Usia Dasar (Studi Era Darurat Covid 19)," J. Bunayya, vol. I, no. 1, hlm. 53-68, 2020.

[2] R. Indonesia, "UU NOMOR 2003," 2003.

[3] D. A. N. Pratama, "TANTANGAN KARAKTER DI ERA REVOLUSI INDUSTRI 4.0 DALAM MEMBENTUK KEPRIBADIAN MUSLIM," $A L$ TANZIM J. Manaj. Pendidik. ISLAM, vol. 3, no. 1, hlm. 198-226, Jun 2019, doi: 10.33650/altanzim.v3i1.518.

[4] K. Wathoni, "INTERNALISASI PENDIDIKAN KARAKTER DI PERGURUAN TINGGI: Studi Kasus di Jurusan Tarbiyah STAIN PONOROGO," Didakt. Religia, vol. 2, no. 1, Mei 2016, doi: 10.30762/didaktika.v2i1.130.

[5] Zubaedi, "Desain pendidikan karakter: konsepsi dan aplikasinya dalam lembaga pendidikan / Zubaedi Pendidikan karakter: implementasi aswaja sebagai nilai pendidikan karakter / M . Mahbubi Pendidikan karakter: menjawab tantangan krisis multidimensional / Mansur Mu," hlm. 1-2, 2012.

[6] S. Judiani, "Implementasi Pendidikan Karakter di Sekolah Dasar Melalui Penguatan Pelaksanaan Kurikulum," J. Pendidik. Dan Kebud., vol. 16, no. 9, hlm. 280, Okt 2010, doi: 10.24832/jpnk.v16i9.519.

[7] D. A. N. Pratama, "Tantangan Karakter Di Era Revolusi Industri 4.0 Dalam Membentuk Kepribadian Muslim," Al-Tanzim J. Manaj. Pendidik. Islam, vol 3, no. 1, hlm. 198-226, 2019, doi: 10.33650/altanzim.v3i1.518.

[8] M. A. Ghufron, "REVOLUSI INDUSTRI 4.0: TANTANGAN, PELUANG DAN SOLUSI BAGI DUNIA PENDIDIKAN," hlm. 6, 2018. 
[9] D. Lase, "Pendidikan di Era Revolusi Industri 4.0," SUNDERMANN J. Ilm. Teol. Pendidik. Sains Hum. Dan Kebud., vol. 1, no. 1, hlm. 28-43, 2019, doi: 10.36588/sundermann.v1i1.18.

[10] K. Harto, "TANTANGAN DOSEN PTKI DI ERA INDUSTRI 4.0," J. Tatsqif, vol. 16, no. 1, hlm. 115, Jul 2018, doi: 10.20414/jtq.v16i1.159.

[11] H. Basri, A. Suhartini, dan Karman, "Pendidikan Agama Islam Dan Pemeliharaan Diri (Hifzh an- Nafs) Di Tengah Wabah Virus Corona," 2020.

[12] Maemunah, "Membangun Pendidikan yang Mandiri dan Berkualitas pada Era Revolusi Industri 4.0 Aula Universitas Muhammadiyah Mataram 1," vol. PISSN 262, no. September, hlm. 1-9, 2018.

[13] Zidniyati, "THE IMPLEMENTATION OF VALUES COMPREHENSIVE APPROACH IN DEVELOPING CHARACTER IN AN ELEMENTARY SCHOOL IN BANYUWANGI (An Observational Report)," vol. 2, hlm. 286-298, 2017.

[14] Nurkholis, "PENDIDIKAN DALAM UPAYA MEMAJUKAN TEKNOLOGI,” vol. 1, no. 1, hlm. 24-44, 2013.

[15] A. Datuk, "PENDIDIKAN MUHAMMADIYAH DALAM MEMANTAPKAN KARAKTER SISWA DI SMA MUHAMMADIYAH KUPANG UNTUK MENYIAPKAN GENERASI 2045," hlm. 7, 2019.

[16] A. Datuk, "PENDIDIKAN MUHAMMADIYAH DALAM MEMANTAPKAN KARAKTER SISWA DI SMA MUHAMMADIYAH KUPANG UNTUK MENYIAPKAN GENERASI 2045," $\mathrm{hlm}$. 7, 2019.

[17] H. Prasetyo dan W. Sutopo, "Industri 4.0: Telaah Klasifikasi Aspek Dan Arah Perkembangan Riset," Jti Undip J. Tek. Ind., vol. 13, no. 1, hlm. 17, 2018, doi: 10.14710/jati.13.1.17-26.

[18] Zidniyati, "Penguatan Pendidikan Karakter di Sekolah Dasar di Era Revolusi Industri 4.0,” vol. 3, no. 1, hlm. 41-58, 2019.

[19] A. Sudrajat, "Mengapa Pendidikan Karakter?," vol. 1, hlm. 47-58, 1M.

[20] S. Sayyidi dan M. A. H. Sidiq, "Reaktualisasi Pendidikan Karakter di Era Disrupsi," Bidayatuna J. Pendidik. Guru Mandrasah Ibtidaiyah, vol. 3, no. 1, hlm. 105, Apr 2020, doi: 10.36835/bidayatuna.v3i01.520.

[21] Syahrul dan Arifin, “JI 3 (2) (2018) JPK Jurnal Pancasila dan Kewarganegaraan," JPK J. Pancasila Dan Kewarganegaraan, vol. 3, no. 2, hlm. 48-55, 2018, doi: 10.24269/jpk.v3.n2.2018.pp1-9. 